\title{
Ethnic monitoring and social control: Descriptions from juveniles in juvenile care institutions Goran Basic
}

\section{Purpose:}

Previous research has emphasized the institutional racism in total institutions. Researchers have highlighted the importance of narratives but have not focused on narratives about ethnic monitoring and social control. This article tries to fill this gap by analysing stories related to descriptions of ethnic monitoring and social control as told by juveniles of non-Swedish ethnicity in Swedish juvenile care institutions. A juvenile's ethnicity was highlighted by drawing attention to the staff's monitoring and social control. Interviews elucidated the victimhood that non-Swedish juveniles portrayed in relation to the staff and/or Swedish juveniles. When juveniles of non-Swedish ethnicity described ethnic monitoring and social control, they generally distanced themselves from staff behaviour and portrayed a victim identity. In constructing their identity, juveniles sometimes used their ethnic background rhetorically when describing everyday situations in the institution. The juveniles portrayed a humiliated self through dissociation from the staff and through the descriptions that they were treated differently than Swedish juveniles.

\section{Design/Methods/Approach:}

Forty-one juveniles placed in SiS special youth care institutions were interviewed. Twenty-two were boys and nineteen were girls. All the interviewed juveniles were between 15 and 20 years old. Eighteen were ethnic Swedes and 23 were of other ethnic origins (background information regarding the informant sex and ethnicity was based on field notes taken before, during, and after the interviews). The general starting point of the study was an ethno-methodologically inspired perspective on verbal descriptions. I was also inspired by the interactionist perspective, which considers interactions expressed through language, actions, and gestures. This inquiry was mainly based on discursive tradition in sociology, where descriptions are considered both experience-based and narrative (Riessman 1993; Potter 1996/2007). In addition to this general starting point, I focused on ethnicity as a particularly relevant component in the specific narratives that I examined. 


\section{Findings:}

In this paper, I analysed the accounts of different participants' behaviour and I observed sequences in which monitoring and social control at the institutions was reproduced and made evident by juveniles with non-Swedish ethnicities.

One starting point of the analysis was the view of Thomas Hylland Eriksen (1993, 2001, 2007) on ethnicity as an ongoing relationship-building process between participants. When monitoring and social control in the institution was revealed, (1) juveniles distanced themselves from the staff's behaviour, and (2) juveniles presented their victim identity. Ethnic monitoring at an institution is a type of monitoring, where the juveniles in the observed situations or descriptions actualized their own ethnic background or that of other individuals. We can distinguish both explicit and implicit types of ethnic monitoring. Explicit ethnic monitoring was evident in cases where the institutional staff member was physically present in the described or observed situation. Implicit ethnic monitoring can also be said to be constantly present (even when institutional personnel were not present) in the fact that in these institutions the juveniles are mainly formed by a collective of non-Swedish youngsters. Ethnic social control in an institution is a type of social control, where the juveniles actualized their own ethnic background or that of other individuals. More specifically, this was the reproduction and enactment of situations where juveniles were regulated into acting in accordance with the staff's (or the institution's) rules, norms, and values, which, at the same time, portrayed their own ethnic background, or that of the other individuals. The analysis showed that, when juveniles exhibited ethnic monitoring and social control, they often drew attention to the staff's morally despicable behaviour.

These two phenomena, ethnic monitoring and social control, are often difficult to isolate in daily interactions. Typically, these two social phenomena appear together; however, there are examples where explicit ethnic monitoring was exercised without social control. In addition, the juveniles were not the only ones monitored and controlled. For example, in one case, a boy was said to have reported to the institution manager that the staff members had classified him as a 'blatte'. The control he transmitted to the staff was based on what he found to be morally correct - the moral principle that the staff should not have placed him in a category that he found demeaning. 
When ethnic monitoring and social control in the institution was made evident, the juveniles generally distanced themselves from the staff's behaviour, and they portrayed their victim identity. During construction of their identity, these juveniles tended to use their ethnic background rhetorically when giving accounts of everyday situations at the institution. The

juveniles seemed to portray their humiliated self through their dissociation from the staff and through their perception that they were treated differently from Swedish juveniles. The humiliated self was clearly shaped by recounting situations, and this identity was strengthened when they noted that the staff members and the Swedish juveniles called them 'fucking svartskalle', 'you blatte-cunt', or 'fucking kanakas'.

Keywords:

Victim; Accounts; Identity; Humiliated self; Ethnicity

\section{About the author(s):}

Goran Basic is a lecturer in sociology at the Department of Sociology, Lund University. His research concerns fieldwork in Bosnia and Herzegovina, he has written articles on the post-war society and carried out an evaluation of a project in the juvenile care. Basic's dissertation "When collaboration becomes a struggle. A sociological analysis of a project in the Swedish juvenile care" is based on ethnographic material. Basic is currently analyzing the collaboration between border police and coastguard in the countries of Baltic region.

\section{Corresponding Author:}

Goran Basic

E-mail: goran.basic@soc.lu.se

Address: Department of Sociology, Lund University, Box 114, 22100 Lund, Sweden 